\title{
The Influence of Emotional Intelligence and Persistence on The Income of Small- Scale Peyek Snack Entrepreneurs in Padang
}

\author{
Depni Oktalia ${ }^{1}$, Agus Irianto ${ }^{2}$, Sri Ulfa Sentosa ${ }^{3}$ \\ ${ }^{1}$ Faculty of Economics, Universitas Negeri Padang, Indonesia \\ $\square$ (e-mail) Universitas depnioktalia.1111@gmail.com \\ ${ }^{2}$ Dept. of Economics Education, Faculty of Economics, Universitas Negeri Padang, Indonesia \\ $\triangle$ (e-mail)prof.agus.irianto@gmail.com \\ ${ }^{3}$ Dept. of Economics Education, Faculty of Economics, Universitas Negeri Padang, Indonesia \\ $\square$ (e-mail) sriulfasentosa@yahoo.com
}

\begin{abstract}
This study aims to reveal how emotional intelligence and persistence affect the income of entrepreneurs who own a small-scale industry of snack called peyek in city of Padang. This study is a descriptive and associative research. In this study, the research populations were 82 entrepreneurs of small-scale industries of peyek in Padang. The two stages cluster random sampling technique was used to determine the sample and the result obtained were a sample of 41 . The research data were collected using a survey questionnaire which were tested for its validity and reliability before. The data analysis technique used in this study is path analysis. The results of this study indicate that emotional intelligence significantly affects entrepreneurs' persistence and emotional intelligence significantly affects entrepreneurs' income. Persistent is not only focusing on earning a high income, but also being equipped with emotional intelligence and other entrepreneurial abilities.
\end{abstract}

Keywords: revenue, emotional intelligence, and persistence

\section{Introduction}

Small scale industries are parts of national economic system which is aimed at reducing the economic disparity, poverty alleviation and employment. According to government laws number 3 in 2014 about Industries, it is explained that small industry is a potential business that is strongly encouraged by the government as more and more entrepreneurs out there are better and stronger the economy of a region. In the present era, all economic activities have become more sophisticated. Production activities that were initially manuals that requires a lot of manpower and long time, is now getting faster by using machines. As well as marketing activities, anywhere and anytime can make buying and selling transactions by utilizing the internet network. The emergence of this digital era can be an opportunity and also a threat to small-scale industry entrepreneurs. Opportunities for entrepreneurs if they follow technological developments, but become a threat if he is not ready to make changes in accordance with the demands of the times. In the digital era is very much the ease of getting the small-scale industry entrepreneurs in development the business.

Kinds of small scale industry that mostly cultivated is the industry of a snack called peyek (rakik). According to Indonesian Dictionary (2018), peyek is a snack (side dish) made of flour with beans (shrimp, and so on), fried in a flat shape. Peyek is quite popular because it is both delicious to be a side dish or just to be everyday snack. As reported in Kompas.com on 28 June 2017, one of the most popular snack Padang is rakik macho. In the city of Padang is usually shelved in innovate with small fish (macho), peanuts and shrimp.

The industry of peyek has several advantages since this snack can be consumed by anyone, people are interested in doing this business, the cost of production is also cheap and the production process is easy. The excellence owned by this industry and supported by the development of Padang, can be an opportunity for the citizens of this city to become entrepreneur of peyek industry. More 
entrepreneurs in Padang will help assisting the use of human resources and increase the revenue of this city. The basic concept of any industry aims to maximize its business revenue. Revenue depends on price of the products and how many the products sold (Nicholson, 2005: 249). Based on data taken from Industry and Trade Office of West Sumatra, the growth of industrial production value can be seen in Table 1.

Table 1 Growth of peyek production value in Padang

\begin{tabular}{ccccc}
\hline Year & $\begin{array}{c}\text { Sum } \\
\text { (Unit) }\end{array}$ & $\begin{array}{c}\text { Total Production Value } \\
\text { (IDR) }\end{array}$ & $\begin{array}{c}\text { Average } \\
\text { (IDR) }\end{array}$ & $\begin{array}{c}\text { Growth } \\
(\%)\end{array}$ \\
\hline 2011 & 54 & $3,563,378$ & 65,988 & \\
2012 & 54 & $3,501,378$ & 64,840 & -1.74 \\
2013 & 87 & $5,795,682$ & 66,617 & 2.74 \\
2014 & 132 & $6,524,909$ & 49,431 & -25.80 \\
2015 & 82 & $4,041,995$ & 49,293 & -0.28
\end{tabular}

Source: Trade and Industry Office of West Sumatera (2017)

These data indicate that the growth in value of production has decreased. This means that the decline in the value of production causes a decrease in sales, resulting in revenue also decreasing. To be a successful entrepreneur, a businessman must have the principles of having little to no fear of failure, passion, creative and innovative, careful in taking risks, patient, tenacious and diligent, optimistic, never give up and care about the environment (Saiman, 2014, 57). Factors influencing entrepreneurial success consist of factors of entrepreneur condition and ability, business characteristic, business location and capital (Private, 2000, 201; Vidyatmoko and Rusadi, 2015; Pamungkas, 2014).

The condition and ability of entrepreneurs is an internal aspect that will be capable to control entrepreneurs in running a business to a success. They consists of self-awareness aspects, the ability to reflect on what happens (emotional intelligence), recognizing and correcting weaknesses, responsible for solving problems and the ability to generate solutions (persistence)(Irawan and Mulyadi, 2016).

Emotional intelligence is an important aspect that entrepreneurs must have in running a business (Agustian, 2001: 8). Emotional intelligence is the ability to know what oneself and others feel (Martin, 2003: 23); one's ability to control, use or express emotions in a way that producessomething good (Salovey and Mayer in Respati et al., 2007). A person with high emotional intelligence will be more adaptable to the work environment (Sai, et al.2011); Emotional intelligence comes out when a person uses his competence at the right time and place (Safarnia et al., 2011). Individuals, who have good emotions, tend to have the will and improve quality in work (Goleman, 2005). Characteristics of emotional intelligence consists of extroversion, agreeableness, conscientiousness, emotional stability, and openness (Martin, 2003: 22); self-awareness, self-regulation, desire for success, empathy and social skills (Goleman, 2005).

Another factor that affects the income is entrepreneur persistence. Being persistent means working hard vigorously in running a business as well as continuous efforts in dealing with difficulties, challenges, or obstacles ( $\mathrm{Wu}$ et al., 2007); loyalty, persistence, individual positive attachment to something that is being done (Lexmond and Reeves, 2009); continuation of easy action even if there are failures, obstacles, or threats, whether it is real or being imagined (Cardon\& Kirk, 2013). Persistence in entrepreneurship includes aspects of self-acceptance, perspective on phenomena, the courage of taking risks, attitudes to challenges, and learning ability (Sunaryo, 2016); control, origin and ownership, reach, and endurance (Wijaya, 2007).

The ability to motivate oneself is closely related to persistence, because persistence depends on the nature of emotion, namely enthusiasm and the desire to face challenges (Putri, 2011). The emotional 
part of a person determines the limits of the ability to utilize the innate mental ability and determines success in life, as well as how the individual is motivated by a sense of enthusiasm and satisfaction towards what is done so that it encourages someone to be excellent.

The research hypotheses for this study are as follows.

$\mathrm{H}_{1}$ emotional intelligence significantly affects entrepreneurs' persistence

$\mathrm{H}_{2}$ emotional intelligence significantly affects entrepreneurs' income

$\mathrm{H}_{3}$ persistence significantly affects entrepreneurs' income

\section{Methods}

The type of research used in this study is descriptive and associative research. Descriptive research is research that aims to describe and interpret the current situation while associative research is research that aims to see the relationship between independent variables (exogenous) and dependent variables (endogenous), and how strong the relationship is (Umar, 2011:22). Exogenous variables in this study are emotional intelligence, while endogenous variables are persistence and income of entrepreneurs.

The type of data used is primary and secondary data. Primary data was obtained by distributing questioner to small industry of peyek in Padang city while the secondary data was acquired from the Industry and Trade Office of West Sumatra. The population in this study is the small-scale industry entrepreneurs in the city of Padang as many as 82 people. To determine the sample, Two Stage Cluster Random Sampling technique is used and obtained by total sample as many as 41 people. The technique used in collecting data is by using questionnaires. The distributed questionnaire consists of a number of statements using the Likert scale with the scale of strongly agree (SA) to disagree (D). The distributed questionnaires are first tested with validity and reliability tests. Data analysis model used is path analysis.

\section{Results and Discussion}

The level of net income by respondents for one month showed in the table below.

Table 2 Distribution of frequency of income

\begin{tabular}{cccll}
\hline No & Income (IDR) & $\mathrm{Fi}$ & $\%$ & \multicolumn{1}{c}{ Information } \\
\hline 1 & $>3,500,000$ & 3 & 7.3 & Higher \\
2 & $2,500,000-3,500,000$ & 4 & 9.8 & High \\
3 & $1,500,000-2,500,000$ & 8 & 19.5 & Medium \\
4 & $<1,500,000$ & 26 & 63.4 & Low \\
& Total & 41 & 100 & \\
\hline
\end{tabular}

Source: Processed SPSS Data, 2018

Table 2 shows the distribution of the income frequency of small-scale industry entrepreneurs of peyek in Padang. The income earned is at a low level measured by using the method of calculating financial analysis, is by reducing revenues with direct expenses incurred which includes the cost of raw materials, transportation, wages paid and rent.

Table 3 Frequency distribution of emotional intelligence

\begin{tabular}{clcccl}
\hline No. & \multicolumn{1}{c}{ Indicators } & $\begin{array}{l}\text { Total } \\
\text { Scores }\end{array}$ & Mean & $\begin{array}{c}\text { TCR } \\
(\%)\end{array}$ & Category \\
\hline 1 & Self-awareness & 158.00 & 3.85 & 77.07 & Adequate \\
2 & Self-regulation & 153.83 & 3.75 & 75.04 & Adequate \\
3 & Success will & 149.17 & 3.64 & 72.76 & Adequate \\
4 & Empathy & 146.25 & 3.57 & 71.34 & Adequate \\
5 & Social skill & 155.00 & 3.78 & 75.61 & Adequate \\
& Average Variable & 152.45 & 3.72 & 74.37 & Adequate \\
\hline
\end{tabular}

Source: Processed SPSS Data, 2018 
Basically, the cost of production includes all costs, whether issued directly or indirectly, including own wages. After an economic analysis of the income of small industry entrepreneurs of peyek, the income earned is minus or loss. This means that the income of small-scale industry of peyek in Padang has not been able to cover the expenses and energy spent in the production of this product. Thus, the analysis used to calculate the income in this study is financial analysis. Furthermore, the proportion of responses given by respondents to emotional intelligence can be seen in Table 3.

Table 3 explains that emotional intelligence variable of small industry entrepreneurs is adequate enough with characterized by an indicator of emotional intelligence that is also in the 'quite well' category. Further achievements of respondents to persistence can be seen in table 4 .

Table 4 Distribution frequency of persistence variables

\begin{tabular}{clcccl}
\hline No. & \multicolumn{1}{c}{ Indicators } & $\begin{array}{c}\text { Total } \\
\text { Scores }\end{array}$ & Mean & $\begin{array}{c}\text { TCR } \\
(\%)\end{array}$ & Category \\
\hline 1 & Self-acceptance & 171.00 & 4.17 & 83.41 & Ample \\
2 & Perspective of phenomenon & 156.50 & 3.82 & 76.34 & Adequate \\
3 & Taking risk courage & 130.86 & 3.19 & 63.83 & Deficient \\
4 & Problem perception & 149.00 & 3.63 & 72.68 & Adequate \\
5 & Learn a lesson ability & 142.00 & 3.46 & 69.27 & Adequate \\
\hline & Average Variable & 146.70 & 3.66 & 73.11 & Adequate \\
\hline
\end{tabular}

Source: Processed SPSS Data, 2018

Table 4 show that the small industrial entrepreneur has successfully accepted himself as a small industrial entrepreneur, but they do not have the courage to take risks, so there is no product diversity compared with other entrepreneurs.

The analysis model used is path analysis. Path analysis will present the amount of direct and indirect relationship between exogenous variables and endogenous variables (Irianto, 2010: 283). The path analysis model in this study consists of 2 sub-structures.

Table 5 Results of model substructure I

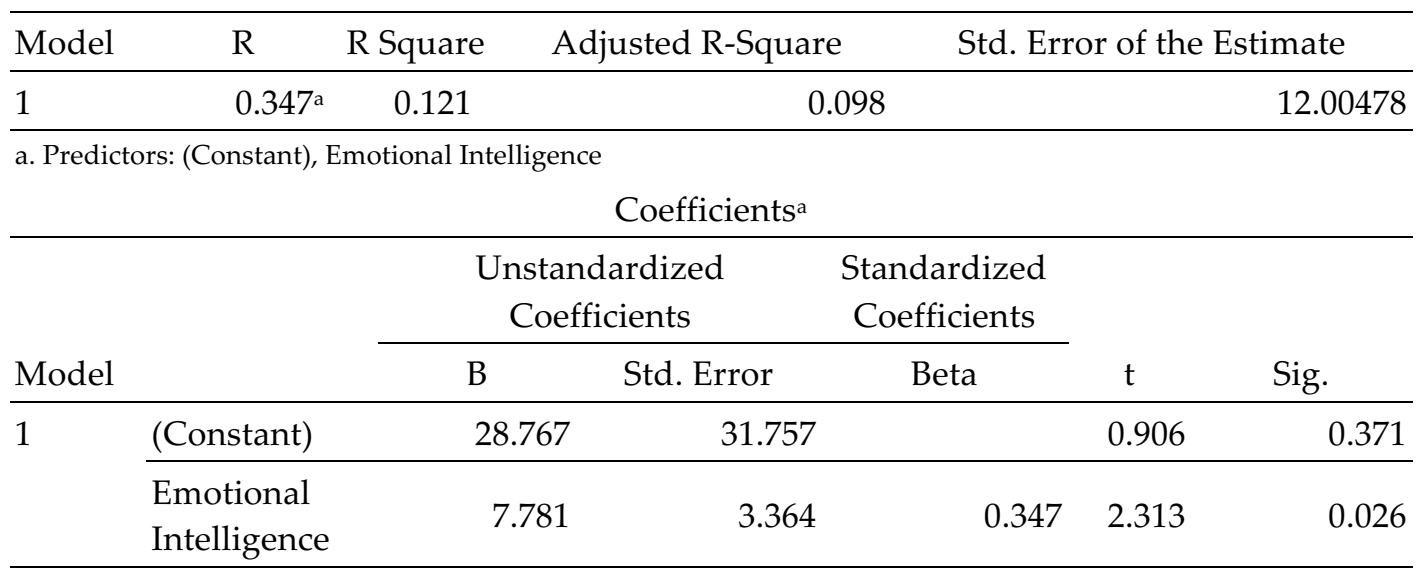

a. Dependent Variable: Persistence

Source: Processed SPSS Data, 2018

The result of the analysis above shows that the significance value of emotional intelligence variable is $0.026<\alpha 0,05$. These results provide the conclusion that sub-structural model 1 has a significant effect on entrepreneur persistence. The path coefficient is 0.347 . Contribution given by emotional intelligence to entrepreneur persistence is $12,1 \%$ while the rest is equal to $87.9 \%$ which is a contribution from other variables that is not included in this research. The coefficient degree of the influence of other variables ( $P \times 2 \varepsilon 1)$ is $P \times 2 \varepsilon 1=\sqrt{1-R^{2} x_{1} x_{2}}=0.937$. Based on the results of the analysis obtained sub-structure model I is shown in Figure 1.

The results of this study indicate that emotional intelligence significantly affects entrepreneurial enthusiasm. High and low emotional intelligence will determine the high and low persistence. This study proves that entrepreneurs who have a good level of emotional intelligence will be able to 
improve and contribute well, especially to the persistence of small scale industry entrepreneur in Padang.

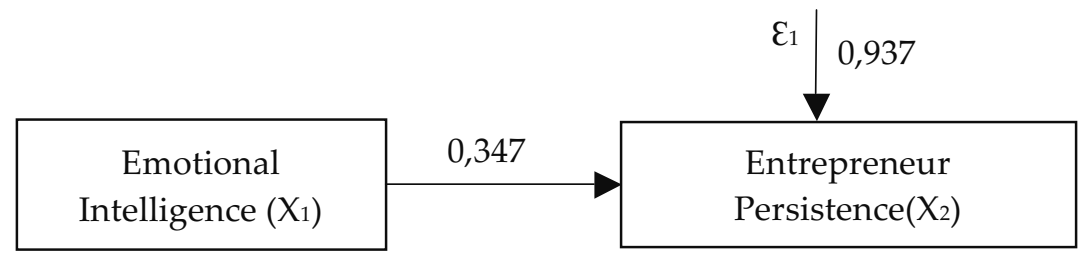

Figure 1 Model of substructure 1

Based on the picture above the equation can be made as follows:

$$
\begin{aligned}
X_{2} & =P_{2} X_{1} X_{1}+\varepsilon_{1} \\
& =0,347 X_{1}+0,937 \varepsilon_{1}
\end{aligned}
$$

In line with Cardon and Kirk's findings (2013) that self-regulation has proven successful in encouraging persistence. Self-regulation is how an entrepreneur is able to handle his emotions well so it has a positive impact on the implementation of tasks and achievement of a goal. When a person has a high degree of self-regulation of a job, they will survive even though their business is experiencing difficulties because they believe the work will be successful in the end.

This finding is consistent with Pajares (2003) who revealed that a person with emotional intelligence competencies can have choices, perseverance, and persistence during the task in order produce something better. Entrepreneurs who are able to manage their emotions well will be able to make choices related to problem solving in running their business and be able to maintain their business in difficult conditions.

Table 6 Analysis Results of Substructure Model II

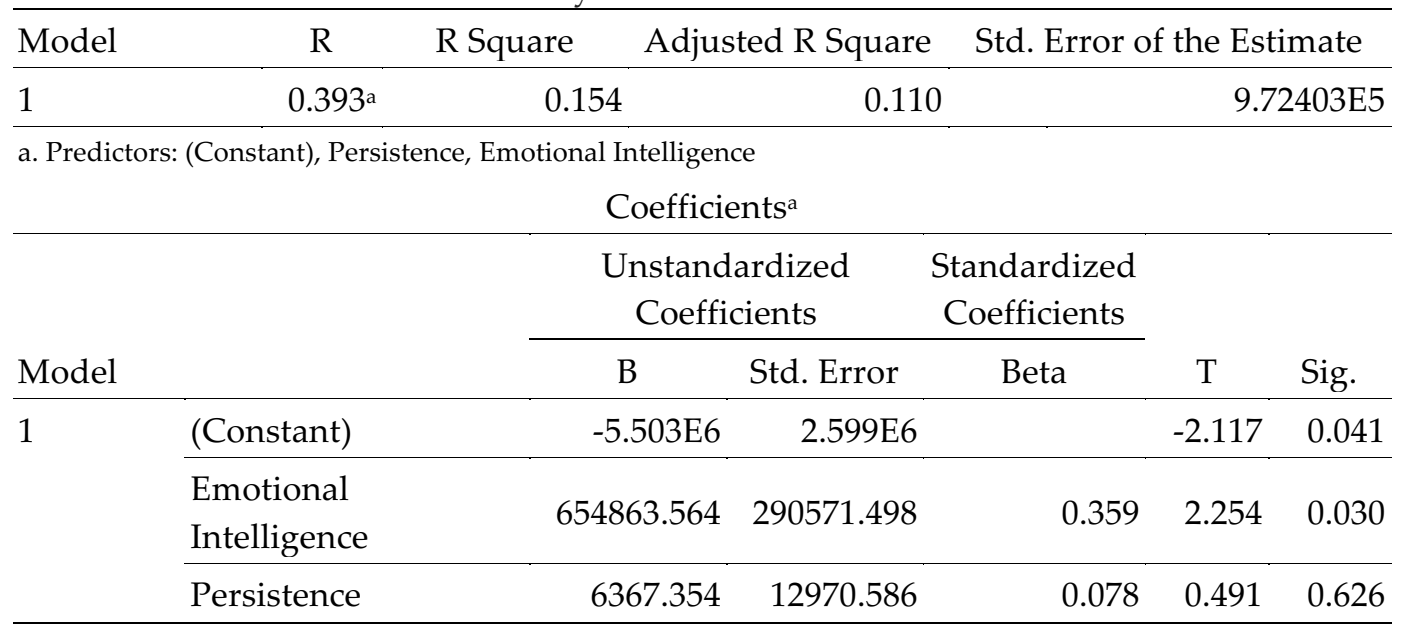

a. Dependent Variable: Business Income

Sumber: Olahan data SPSS 16, 2018

Based on Table 6 it can be seen that the significance value of emotional intelligence variable is $0,030<\alpha 0.05$, while the value of persistence significance is $0.426>\alpha 0.05$. These results give the conclusion that in the sub-structure model II emotional intelligence significantly affects entrepreneurs' income while persistence has no significant effect on it. The coefficient value of $X_{1}$ to $Y$ is $\operatorname{Pyx} 1=0.359$ and coefficient $\mathrm{X}_{2}$ to $\mathrm{Y}$ is $\mathrm{Pyx}_{2}=0.078$. The amount of contribution of the influence of emotional intelligence $\left(\mathrm{X}_{1}\right)$ and persistence $\left(\mathrm{X}_{2}\right)$ to the income of entrepreneur $(\mathrm{Y})$ is $15,4 \%$ while the rest is $84.6 \%$ which is contribution from other variables that is not included in this research. The magnitude of the coefficient of the path of influence of other variables (PyEz) is PyE2 = $\sqrt{1-R^{2} x_{1} x_{2} y}=0,920$. Based on the analysis, the sub path analysis model of structure II is shown in Figure 2 . 


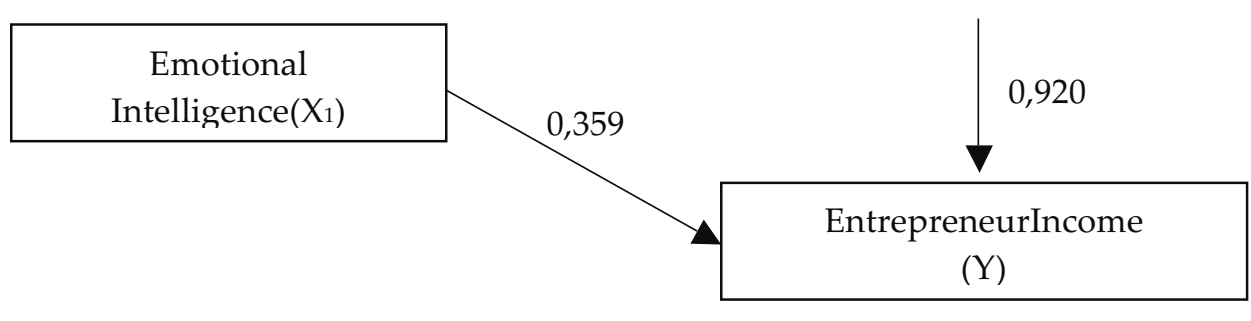

\begin{tabular}{|c|}
\hline Persistence \\
$\left(\mathrm{X}_{2}\right)$ \\
\hline
\end{tabular}

0,078

Figure 2 Sub-structure II

Based on the picture above the equation can be made as follows:

$\mathrm{Y}=\mathrm{Pyx}_{1} . \mathrm{X}_{1}+\mathrm{Pyx}_{2} . \mathrm{X}_{2}+\varepsilon_{2}$

$=0,359 X_{1}+0,078 X_{2}+0,920 \varepsilon_{2}$

The results of the analysis show that emotional intelligence significantly affects the income of entrepreneurs and the form of influence is positive. This means that if the entrepreneur has a good level of emotional intelligence, the income will also increase. In line with findings of Oriarewo et al. (2014) which states that there is significant influence of emotional intelligence on entrepreneurs' performance. The application of emotional intelligence and entrepreneurial competence improves entrepreneurs work performance. This is because the ability of emotional intelligence plays an important role in entrepreneurial activities, such as identifying and exploiting opportunities, obtaining finance, making decisions, choosing business partners, selecting employees, establishing and maintaining relationship with employees and customers and leading organizations.

Wijayanto (2013) also proves that intelligence and emotional skills of a person have a positive and significant impact on business success. This study found that the factors of ability to build relationship with customers, employees, suppliers, and so on became the decisive factor for business success. Those who lack social skills mostly fail to establish relationship with suppliers, retailers and consumers of their products, so that they are unable to cope with raw material constraints and market development.

Persistence has no significant effect to the income of small-scale industry entrepreneurs of peyek in Padang, it can be seen from the analysis of persistence frequency distribution that entrepreneurs lack the courage to take risk with TCR value of $63.83 \%$, it means that entrepreneur has not been able to do product differentiation whether in terms of taste or appearance of the product, so they are still producing the same products with its competitors. The entrepreneurs also have the ability to learn well enough with the value of TCR of $69.27 \%$, meaning that entrepreneurs are still not able to learn from the experiences during running the business, so that the undertakings run undeveloped.

In line with the findings of Akhriani and Widyaiswara (2016) stating that hard work alone is not enough to achieve the best performance, but be obliged to work smart as well. Carrying out the work is not only relied on physical force and strength, but also using creative and innovative views that are used to enhance the work. Gemina et al. (2016) also revealed that passion is not enough for an entrepreneur, but he must have knowledge about all aspects of the business he does, have knowledge of practice in technique, have skills in numeracy and have the skills in communicating as well.

Meanwhile the cause of no effect of persistence in entrepreneur income is that persistence must be moderated by business ability. As disclosed by Gemina et al. (2016) the business ability strengthens the relationship of passion with the business success. Entrepreneurs who have high passion in working and are supported by business ability will be able to increase the business success (business income). Thus, the ability of entrepreneurship is a function of entrepreneurial behavior in combining creativity, innovation, persistence, and courage to face risk to obtain opportunities. 
From the results of data processing and discussion, it can be formulated a path structure and the influence of exogenous variables on endogenous variables in the following figure:

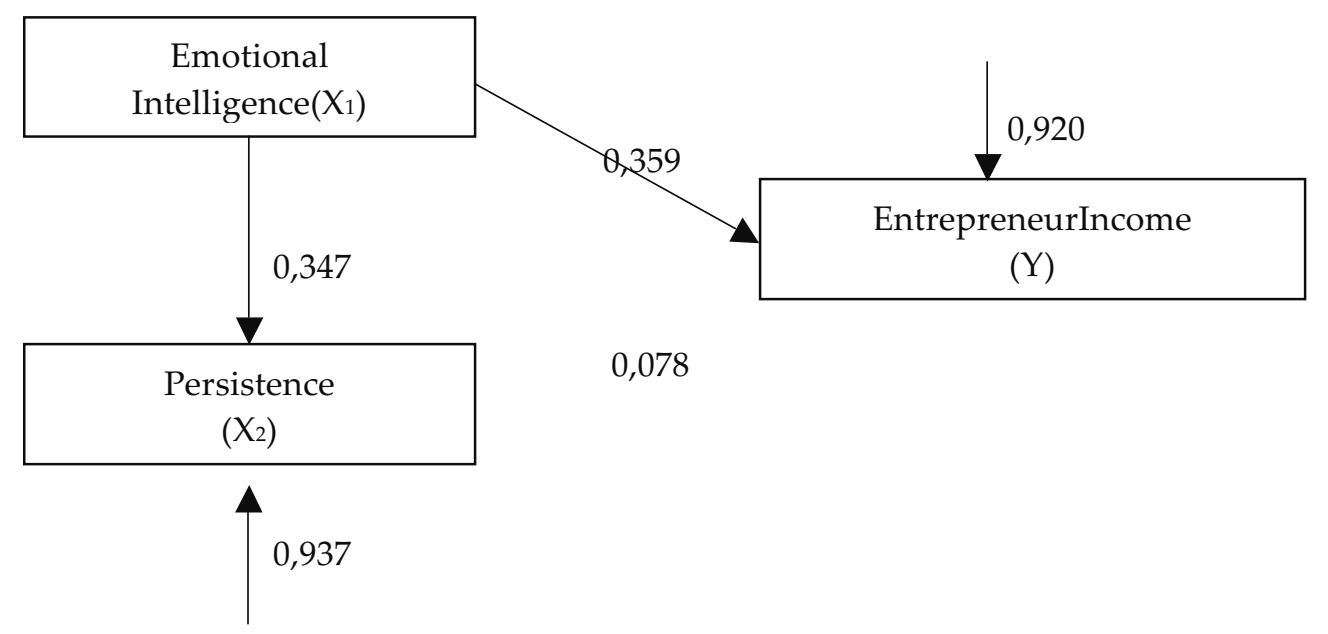

Figure 3 Path analysis structure

\section{Conclusions}

Based on the results of research and discussion about the influence of emotional intelligence and persistence to the income of small-scale industry entrepreneurs of peyek in the city of Padang can be drawn the following conclusions:

1. Emotional intelligence has a significant effect on the persistence of small scale industry entrepreneurs in Padang. The form of its influence is positive. This means that if the emotional intelligence is improved then persistence will also increase.

2. Emotional intelligence significantly affects the income of small-scale industry entrepreneurs of peyek in Padang. The form of its influence is positive. This means that if the emotional intelligence is increased then the income will also increase.

3. Persistence variable has no significant effect to the income of the small-scale industry entrepreneurs of peyek in Padang. Persistence alone is not enough to earn a high income, but also must be equipped with emotional and other entrepreneurial abilities.

\section{Acknowledgment}

I would like to express my gratitude to Trade and Industry Office of Padang for providing data of the development of small scale industry of peyek snack so that I can continue to research. Especially to all of the small-scale industry entrepreneurs of peyek in Padang for participating in giving information regarding emotional intelligence, persistence and revenue of their business that allow the authors to conduct this study.

\section{Reference}

Agustian, Ary Ginanjar. (2001). Rahasia Sukses Membangun Kecerdasan Emosi dan Spritual (ESQ). Jakarta: ARGA Publishing.

Akhriani, Dessi \& Widyaiswara. (2016). Memaknai Bekerja Keras, Bekerja Cerdas. Retrieved on 19 April 2018 from https:// bdkpadang.kemenag.go.id.

Cardon \& Kirk. (2013). Entrepreneurial passion as mediator of the self-efficacy to persistence relationship. Retrieved on 5 September 2017 from http://s3.amazonaws.com.

Gemina, dkk. 2016. Pengaruh motivasi usaha terhadap keberhasilan usaha dengan kemampuan usaha sebagai variabel mediasi pada industri kecil menengah makanan ringan Priangan Timur-Indonesia. Retrieved from http://journal.sbm.itb.ac.id. 7 July 2018.

Goleman, D. (2005). Working with Emotional Intelligent. Jakarta: Gramedia Pustaka Utama. 
Goverment laws number 3 in 2014 about Industries

Irawan, Ari dan Mulyadi, Hari. (2016). Pengaruh keterampilan wirausaha terhadap keberhasilan usaha. Journal of Business Management and Enterpreneurship Education, 1(1), 213-223. Retrieved on 16 July 2017 from http://ejournal.upi.edu.

Irianto, Agus. (2010). Statistik; Konsep Dasar, Aplikasi, dan Pengembangannya. Jakarta: Kencana.

Lexmond, J., \& Reeves, R. (2009). Building Character. London: Mixed Sourced.

Martin, Anthony Dio. (2003). Emotional Quality Management. Jakarta: Aga.

Nicholson, Walter. (2005). Microeconomic Theory. United States of America: Thomson

Oriarewo, et.al. (2014). Influence of emotional intelligence on entrepreneurial performance: an empirical analysis of the hospitality industry in Makurdi, Benue State, Nigeria. International Journal of Academic Research in Management (IJARM), 3(4). Retrieved on 6 September 2017 from http://elvedit.com.

Pajares, Frank. 2003. Self-Efficacy Beliefs, Motivation, and Achievement in Writing: A Review of The Literature. Retrieved from http://uky.edu.ac.id. 7 July 2018.

Pamungkas, Rizki. 2014. Faktor-faktor yang Mempengaruhi Keberhasilan Usaha Pemegang Usaha Waralaba. Retrieved from http://eprints.undip.ac.id. 16 July 2017.

Putri, Kadek Sri Eka. 2011. Hubungan kecerdasan emosi dan kesiapan belajar dengan prestasi belajar. Retrieved from https://eprints.uns.ac.id. 6 September 2017.

Respati, S Winanti, Arifin P. Wilda, dan Ernawati. (2007). Gambaran kecerdasan emosional siswa berbakat di kelas akselerasi sma di jakarta. Jurnal Psikolog. Retrieved on 5 July 2017 from http://digilib.esaunggul.ac.id.

Sunaryo. (2016). Peningkatan hasil belajar dan kegigihan siswa pada pelajaran kewirausahaan melalui pembelajaran model discovery inkuiri dan penugasan di smk muh 2 metro tahun pelajaran 2012/2013, 4(1), 74-83. Retrieved on 5 July 2017 from http://download. portalgaruda.org.

Swasta, Basu dan Irawan. (2000). Manajemen Pemasaran Modern. Yogyakarta: Liberty.

Vidyatmoko, Dyan dan Rosadi, A. Husni Yasin. (2015). Faktor utama kesuksesan wirausaha di industri pangan. Jurnal Manajemen Teknologi, 14(1). Retrieved on 16 July 2017 from http://journal sbm.itb.ac.id.

Wijaya, Tony. (2007). Hubungan adversity intelligence dengan intensi berwirausaha. Jurnal Manajemen dan Kewirausahaan, 9(2). Retrieved on 6 September 2017 from http://Titiayem.Staff. Gunadarma.ac.id.

Wijayanto, Andi. Pengaruh karakteristik wirausahawan terhadap tingkat keberhasilan usaha. Retrieved on 7 July 2018 from http://eprints.undip.ac.id. 